Linha D'Água (Online), São Paulo, v. 29, n. 2, p. 5-41, dez. 2016

\title{
A INTERAÇÃO ARGUMENTATIVA NO DISCURSO LITERÁRIO: DA LITERATURA DAS IDEIAS AO RELATO DE FICÇÃO
}

\section{THE ARGUMENTATIVE INTERACTION IN THE LITERARY DISCOURSE: FROM THE LITERATURE OF IDEAS TO THE FICTIONAL REPORT}

Ruth Amossy*

Tel Aviv University, Tel Aviv, Israel

Resumo: A dimensão argumentativa do texto literário se expressa na capacidade de orientar a vis̃̃o de seus leitores. A teoria de Perelman inscreve a interação argumentativa no discurso do orador e os trabalhos contemporâneos em Linguística Pragmática e em Narratologia permitem a localizacạ̃o precisa das instâncias interdiscursivas tal como elas se inscrevem no texto, assim como as modalidades de ancoragem social do diapositivo enunciativo, fundando uma aproximação ao texto literário em uma perspectiva dialógica. A argu-

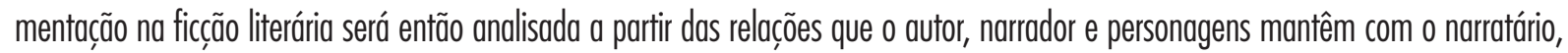
tornando assim aparente a pluridimensionalidade da argumentação no texto literário. Finalmente, a análise argumentativa do discurso de um comício tal como foi colocado em cena pelo escritor Roger Martin du Gard em Os Thibault permite mostrar como o discurso do narrador conduz a uma problematização da argumentação de primeiro nivel, bem como esta se desenvolve na relação orador-auditório.

Palavras-chave: Discurso; Argumentação; Texto literário; Interaç̣̃õo argumentiva.

Abstract: The argumentative dimension of the literary text expresses itself in the capacity to orient the view of its readers. Perelman's theory inscribes the argumentative interaction in the orator's discourse, and the contemporary works of Pragmatics and Narratology allow, on the one hand, the precise localization of interdiscursive instances as they are inscribed in the text and, on the other, the identification of the modalities of social grounding pertaining to the enunciative device, founding an approach to the literary text in a dialogic perspective. The argumentation in the literary fiction will, then, be analyzed through the relations that the author, the narrator and the characcers assume with the narratee, making thus visible the pluridimensionality of argumentation in the literary text. Finally, the argumentative analysis of a rally's speech, as it was represented by the writer Roger Martin du Gard in The Thiabault, affords showing how the narrator's discourse conducts to a questioning of the first level argumentation, as well as how the latter unfolds itself in the relation between the orator and the audience.

Keywords: Discourse; Argumentation; Literary Text; Argumentative Interaction.

* Professora Emérita da Tel Aviv University - TAU, Tel Aviv, Israel; amossy@bezeqint.net 
Linha D'Água (Online), São Paulo, v. 29, n. 2, p. 5-41, dez. 2016

\section{A dimensão argumentativa do discurso literário'}

O renovado interesse que a argumentação ocupa nas ciências da linguagem começa a ser observado por conta dos seus efeitos no campo dos estudos literários². Esta situação nos conduz a perguntar sobre qual perspectiva e no cruzamento de quais disciplinas nos convém desenvolver a análise argumentativa do texto chamado "literário" (isto é, o reconhecido como tal pela instituição). Nesse contexto, é necessário diferenciar entre o que se denomina a "literatura de ideias" e o relato de ficção no sentido amplo do termo "ficção". É claro que um ensaio, um manifesto, ou um panfleto não supõem o mesmo tipo de comunicação que a fábula, o conto ou o romance. Contudo, pode-se buscar um modelo de base comum aos textos que têm a ver com a arte da persuasão, contanto que se determine o sentido e o alcance que se dá à noção de argumentação. De fato, a aproximação variará segundo se define a argumentação como um discurso com um objetivo expressamente persuasivo, como um fenômeno inerente à língua, ou como uma das dimensões próprias de toda a interação verbal.

Em sua acepção original, a da retórica clássica, a argumentação cobre todo o conjunto de discursos que busca atrair a adesão do auditório. Aristóteles falava de três gêneros oratórios: o judiciário, que compreende a acusação e a defesa, o deliberativo, que compreende a persuasão e a dissuasão, e o demonstrativo (epidítico), o discurso de pompa que compreende o elogio e a crítica. Ainda que se considere ou não essas categorias, a época contemporânea ampliou a gama dos discursos

1 Nota dos Orgs: Agradecemos vivamente a Tanya Gonzáles Zavala por autorizar a publicação da tradução deste artigo, a partir da versão em espanhol publicada pela Escritos - Revista del Centro de Ciencias del Lenguaje de la Benemérita Universidad Autónoma de Puebla, número 17-18, 1998. Agradecemos, também, a Ingrid Bomfim Cerqueira (UESC) e a Daniel Mazzaro Villar de Almeida (UNIFAL) pela tradução deste artigo.

2 É possível notar esse interesse no cuidado com que os manuais de retórica e argumentação, tão frequentes ultimamente na França, tratam o texto literário, tal como provam as obras de Reboul (1991), Declercq (1992), Robrieux (1993), Gardes-Tamine (1996). Além disso, e como continuação da obra precursora de Kibédi Varga, de 1970, encontram-se outros trabalhos dedicados à análise argumentativa do texto literário e do relato de ficção, como o livro de Mc Keon (1992), nos Estados Unidos; as obras de Halsall (1988, 1995), no Canadá; Introdução à análise dos textos clássicos, de Forestier (1993); a obra coletiva Que prova a literatura? Ficção e argumentação (1997), na França. 
Linha D'Água (Online), São Paulo, v. 29, n. 2, p. 5-41, dez. 2016

persuasivos ao filosófico, ao publicitário, ao midiático etc. Diante disso, podem-se diversificar e afinar as tipologias, mas o essencial é que a perspectiva retórica continua sendo diferencial e restritiva: só são argumentativos, excluindo todo o resto, os discursos que explicitamente buscam a adesão do público. Assim, no campo das Humanidades, a perspectiva retórica incluirá: Essai sur les préjugés (Ensaio sobre os preconceitos) atribuído a Dumarsais, J'accuse (Acuso) de Emilio Zola, Provinciais, de Pascal, ou também as orações fúnebres de Bossuet. Em uma obra de ficção, podemse destacar as passagens nas quais um personagem tenta fazer aderir um auditório a sua tese. $\mathrm{O}$ fazer jurídico aparece sempre que os protagonistas se acusam ou se desculpam diante da figura de um juiz, o gênero deliberativo "se utiliza em todos os gêneros literários - tragédia, romance, fábula, poesia lírica - cada vez que uma situação apresenta dois personagens que discutem uma ação que devem realizar" (FORESTIER, 1993, p. 47). A análise argumentativa do discurso dos personagens se aplica (sem distinção de gêneros) à arenga de Brutus à multidão em Júlio César (DECLERCQ 1992, p. 189-193), ao parlamento de Ifigênia a seu pai Agamenon decidido a sacrificá-la aos deuses. (FORESTIER, 1993, p. 62-65) ou ao discurso epistolar de Les liasions dangerous (As relaçôes perigosas). (GARDES-TAMIRES, 1996, p. 106-109). Também se pode estender esta análise ao discurso do que se apresenta como enunciador principal de toda obra, com a condição de que se pretenda persuasivo. Seria o caso do poeta Marquise (Marquesa) de Pierre Corneille (REBOUL, 1991, p. 200), o narrador-protagonista de Vitor Hugo em Le dernier jour d'un commdané à mort ( $O$ último dia de um condenado à morte) (HALSALL, 1993) ou o narrador de L'Étape (A Etapa), de Paul Bourget (SULEIMAN, 1983).

Portanto, a análise argumentativa do relato de ficção não deve estar necessariamente circunscrita aos discursos dos personagens, isto é, a determinadas passagens da obra. Contudo, nos casos em que a argumentação se estende a toda a narração, esta corre o risco de ser depreciada. Com efeito, na época contemporânea costuma-se desvalorizar a ficção com valor demonstrativo à qual se colocou a etiqueta equivocada de "romance de teses" (SULEIMAN, 1983). Na medida em que literatura tende cada vez mais desde o século XIX a se converter em pura estética, em uma busca diferenciada de formas, as obras que declaram seu objetivo persuasivo não causam boa impressão. E, por isso, a relação do discurso chamado 
Linha D'Água (Online), São Paulo, v. 29, n. 2, p. 5-41, dez. 2016

literário com a argumentação parece se encontrar em um beco sem saída. Se não possui uma vocação persuasiva no sentido estrito do termo, considera-se que não se trata de argumentação, e se busca a partir de um manifesto a adesão favorável a uma tese, considera-se que não merece o qualitativo de "literário".

Enquanto a retórica atribui um caráter argumentativo aos discursos que mostram de forma clara um objetivo persuasivo, a pragmática integrada estende a argumentatividade à totalidade da língua. Ao considerar que há argumentação quando o locutor "apresenta um enunciado E1 (ou um conjunto de enunciados) que está destinado a fazer admitir outro (ou um conjunto de outros) E2" (ANSCOMBRE; DUCROT 1988, p. 8), Anscrombre e Ducrot afirmam que "é um traço constitutivo de numerosos enunciados, o que não se pode empregar sem pretensão de orientar o interlocutor para um tipo de conclusão" (op. cit., 1988, p. 48). "Inerentes à estrutura dos enunciados”, os encadeamentos, argumentativos não devem ser abandonados “a uma retórica extralinguistica" (op. cit., 1988, p. 9)33: pertencem ao estudo da língua propriamente dita. De forma concreta, a teoria da argumentação na língua pretende demonstrar que é impossível realizar de modo concreto uma análise semântica sem levar em conta a orientação argumentativa dos enunciados. Nesse ponto de vista, é evidente que a argumentação é central no texto literário e o contempla por inteiro, pois integra o nível semântico. Mas, o pragmático interessado pelo funcionamento da língua não examina as modalidades argumentativas próprias dos distintos gêneros do discurso, nem que relação há entre a argumentação e a literatura de ideias, nem se no relato de ficção existem modos de enunciação específicos.

Por conseguinte, de um lado, a pragmática integrada dilui o funcionamento argumentativo do relato de ficção no mais geral da linguagem; e, de outro lado, o ponto de vista retórico tradicional somente observa a argumentação em um número limitado de discursos que ipso facto se encontram depreciados pela instituição literária contemporânea. Dadas essas circunstâncias, entende-se que o estudo argumentativo do texto literário não tenha alcançado uma grande atenção até o momento.

Existe uma terceira posição, que será a nossa, segundo a qual a argumentação é um fato do discurso (e não da língua) que não se limita aos atos deliberados de

3 Ver nota anterior. 
Linha D'Água (Online), São Paulo, v. 29, n. 2, p. 5-41, dez. 2016

persuasão, mas, ao contrário, é inerente a toda interação verbal. Plantin (1996, p. 18) resume essa posição nos seguintes termos:

Toda palavra é necessariamente argumentativa. É um resultado concreto do enunciado na situação. Todo enunciado busca agir sobre seu destinatário, sobre o outro, e transformar sua forma de pensar. Todo enunciado obriga ou incita o outro a crer, ver ou fazer de outra forma.

Nessa perspectiva, o relato de ficção, assim como a conversação cotidiana ou a interação didática, comporta uma dimensão argumentativa, que pode ser mais ou menos perceptível. Esta coexiste com outras dimensões como a descritiva ou a narrativa. Assim como elas, a argumentação não necessita existir em estado puro para se afirmar. Da mesma maneira que a descrição se integra no desenvolvimento do relato e assume diversas funções, a argumentação da ficção pode ser subjacente ao retrato de um personagem ou se misturar no desenvolvimento de um enredo. Ainda que seja dominante em alguns casos, também pode se subordinar ou inclusive se reduzir ao extremo. Por exemplo, em Le Silence de la mer, de Vercors, a tese segundo a qual é necessário em todas as circunstâncias opor ao ocupante alemão uma negativa categórica que orienta e hierarquiza todos os planos do relato.

Entretanto, em um romance como Le Colonel Chabert, de Balzac, a tese aparece mais difusa, quase ambígua, de modo que os leitores chegam a propor explicações divergentes do texto. Contudo, se se observa o início do romance, percebe-se que está organizado de modo que não apenas se apresenta o protagonista, Chabert, e o meio judicial em que ele deverá tentar fazer triunfar sua causa, mas também orienta a perspectiva sobre os acontecimentos relatados. A exclamação desdenhosa do estagiário do tabelião quando vê Chabert pela janela (Ora! Outra vez nosso velho carrick $^{4}$ !) mostra desde o princípio o desprezo com os clientes sem dinheiro: se o hábito não faz o monge, a sobrecasaca desgastada lhe faz um mau cliente. A repressão moral do primeiro estagiário com o subalterno ("Por mais pobre que seja um cliente, é sempre um homem, que droga!") vê-se duplamente desmentida.

4 Levita (ou sobrecasaca). A palavra carrick e o vestido que designa não são utilizados atualmente. 
Linha D'Água (Online), São Paulo, v. 29, n. 2, p. 5-41, dez. 2016

Primeiro, pelo que está realizando nesse momento: para fazer a recriminação ao aproveitador, o primeiro estagiário interrompe "a escrita de uma fatura", e, em seguida, pela contestação do jovem: "Se é um homem, porque o chama de velho carrick $?^{5}$ - disse Simonnim com ar de um aluno que surpreende o seu professor com uma falha" (BALZAC, 1994, p. 36). Deriva-se disso que, na França pós-revolucionária (esse episódio transcorre durante a Restauração), os princípios e a realidade divergem amplamente. A Justiça, que se supõe igual a todos, é, na verdade, negada àqueles que não têm os meios para pagá-la. O relato do Coronel Chabert, privado de sua fortuna e de seus direitos e relegado a um asilo, será uma ilustração que contempla esse primeiro princípio, à primeira vista, anódino.

Essa capacidade de orientar a visão do público ao se submeter de uma forma mais ou menos diretiva um tema de reflexão constitui precisamente a dimensão argumentativa do relato literário. De acordo com suas próprias modalidades, abre ou orienta um debate, revela ou esclarece uma problemática. Se o discurso eleitoral ou publicitário tem como objetivo primordial influir em uma decisão imediata e provocar uma ação (votar no candidato ou comprar o produto), a argumentação em situação de ficção pode, ao contrário, destacar uma questão sem propor uma solução unilateral. O caráter não pragmático do texto de ficção, tantas vezes debatido, não encerra toda possibilidade de argumentação, mas permite que ele desenvolva estratégias de adesão que vão desde o reforço dos valores vigentes até sua problematização. Como já não se trata de produzir um efeito tangível em função do objetivo desejado, a obrigação de univocidade desaparece. A interrogação, o exame não definitivo das contradições, a manifestação das tensões e a complexidade podem se converter em parte integrante da dimensão argumentativa do relato literário. Nessa perspectiva, a análise argumentativa não se aplica apenas aos textos que tentam fazer aceitar uma tese bem definida, mas também àqueles que compartilham um ponto de vista sobre o real, reforçam os valores ou orientam a reflexão.

Tanto no caso de textos que militam por uma tese unívoca como no das obras com uma dimensão argumentativa, o relato de ficção busca atuar sobre o leitor. Faz isso utilizando os meios recolhidos nas retóricas clássicas e modernas, mas também

5 De fato, o apelido "velho carrick" foi atribuído a Chabert pelo primeiro estagiário. 
Linha D'Água (Online), São Paulo, v. 29, n. 2, p. 5-41, dez. 2016

através de seu próprio dispositivo. Nesse ponto, a análise argumentativa se situa no cruzamento da retórica - que se vincula à arte da persuasão - e da pragmática, que estuda as interações verbais. A esses âmbitos teóricos, no caso do relato de ficção, se acrescenta a narratologia, que analisa a questão das vozes narrativas, e se completa com uma teoria da leitura. Consequentemente, é importante elaborar uma aproximação que permita combinar e integrar as contribuições dessas diversas disciplinas.

\section{Perspectivas interacionais sobre a argumentação}

Campos tão diferenciados como os mencionados permitem construir um modelo operatório? E, em caso afirmativo, sobre quais bases comuns? A noção de interação oferece o âmbito em que se pode elaborar uma análise argumentativa. Permite levar em conta, ao mesmo tempo, a materialidade da língua, as técnicas discursivas de persuasão e a especialidade do texto literário. É importante examinar primeiro em que medida certas perspectivas de interação propostas pelos estudos retóricos, pragmáticos e narratológicos (no caso do relato de ficção) se confirmam ${ }^{6}$. Trataremos de extrair alguns princípios tomando nossos exemplos de um texto de Romain Rolland (1914), Au-dessus de la mêlée, no campo da literatura das ideias, e de um episódio de Os Thibault, extraído de L'été 1914, de Roger Martin du Gard (1936/1964), no âmbito do relato de ficção. A proximidade dos temas tratados (o debate sobre a guerra de 1914) permitirá ressaltar a diferença entre a argumentação narrativa e a não narrativa.

\subsection{A retórica}

Segundo Aristóteles, a "retórica é a faculdade de considerar em cada caso o que cabe para persuadir" (1991/1990, p. 10). Para os Clássicos, é "por excelência, a técnica de agir sobre os outros homens por meio do logos, termo que designa de uma

\footnotetext{
6 A noção de interação argumentativa utilizada neste artigo não corresponde ao emprego que dela faz Plantin (1996) quando a define como "uma situação de confrontação discursiva no transcurso da qual se constroem as reações antagonistas frente a uma questão". No nosso caso, limitamo-nos à perspectiva interativa da retórica que privilegia a relação entre o orador e seu auditório, mas modificando o modelo para destacar seu aspecto linguístico e social.
} 
Linha D'Água (Online), São Paulo, v. 29, n. 2, p. 5-41, dez. 2016

forma equívoca tanto a palavra como a razão" (PERELMAN, 1988, p. 10). Perelman define a argumentação na linha aristotélica como "as técnicas discursivas que permitem provocar ou aumentar a adesão das pessoas às teses apresentadas para seu assentimento" (1970/1989, p. 34). É interessante observar que Perelman se refere à retórica clássica como a palavra eficaz que busca influenciar o auditório e que, para conseguir isso, deve adaptar-se a ele: "O orador, se quer agir de modo eficaz através de seu discurso, deve se adaptar ao seu auditório” (PERELMAN, 1988, p. 35). A influência recíproca que um exerce sobre o outro, o orador e o auditório, na dinâmica do discurso com um objetivo persuasivo, leva em conta e constitui uma das pedras angulares da "nova retórica" de Perelman. O orador tenta orientar as decisões e provocar uma ação ou ao menos criar uma disposição à ação suscetível de se manifestar no momento oportuno. Só se pode fazer isso se levarmos em consideração as crenças, os valores, as tendências dos que lhe escutam. Isto é, a inter-relação entre o orador e o auditório é constitutiva. Nesse sentido, o renovado interesse pela arte de persuadir provocado pelos trabalhos pioneiros de Perelman constitui efetivamente a "análise em termos comunicacionais" que Breton (1996, p. 7) tanto deseja.

Por orador, Perelman entende aquele que, indiferentemente, pronuncia ou escreve um discurso. Destaca que ele deve estar habilitado para tomar a palavra pela sua situação institucional, pelas suas qualidades próprias... Trata-se do ethos, sobre o qual a retórica aristotélica insistia e o incluía em uma tríade ao lado do logos (a palavra da razão) e do pathos (as paixões). Nesse quadro, o ethos designava a autoridade do orador. De acordo com Aristóteles (1989/1990, p. 10), é “o caráter moral (do orador) que implica a persuasão, quando o discurso é dito de tal maneira que torna digno de fé o que ele diz”. Perelman (1970/1989, p. 55) entende por auditório, em sentido amplo, "o conjunto formado por aqueles em quem o orador quer influir com sua argumentação". Esse público pode ser específico ou indeterminado, presente ou ausente, formado por apenas uma pessoa ou por uma assembleia numerosa. Não tem por que intervir concretamente para constituir uma peça chave do dispositivo argumentativo. Todos os enfoques retóricos centrados na inter-relação entre os participantes insistem nesse aspecto. Assim, na pragma-dialética de Van Eemeren e Groortendorst (1996, p. 100): 
[...] deve-se considerar que a argumentação dirigida a um interlocutor único ou a um leitor faz parte de um diálogo, inclusive se o outro adota uma atitude passiva e não replica nada [...]. Inclusive diante de um auditório totalmente impassível, quem argumenta e quer alcançar o sucesso antecipará os contra-argumentos possíveis e tentará preparar as supostas objeções.

Portanto, o orador deve construir uma imagem do auditório que lhe permita antecipar as suas reações, superar as objeções e escolher o argumento que convença. Nesse aspecto, a nova retórica de Perelman e Olbrechts-Tyteca contribui com um elemento cuja importância é preciso salientar: ela afirma que o auditório é uma “construção do orador". Nessa perspectiva, pode-se dizer que o auditório é uma fição verbal. Constitui uma ficção tanto porque é construído pelo orador quanto porque não se confunde com o público real, desde que aquele tenha em relação a este um mínimo de fidelidade. A fantasia aqui não serve: a distância entre a imagem elaborada pelo orador e o público empírico determina a eficácia da argumentação. Se a distância é muito grande, se a construção do auditório não se revela "a adequada para a ocasião” (PERELMAN; OLBRECHTS-TYTECA, 1970/1989, p. 55), a ação de persuasão está destinada ao fracasso na prática.

Ao considerar as "opiniões dominantes" e as "conviç̧ões indiscutíveis" que constituem parte da bagagem cultural de seus interlocutores, o orador deve mobilizá-las para construir sua argumentação sobre bases sólidas. A empresa de persuasão exige que se parta de alguns pontos de acordo que, basicamente, irá se esforçar para que seu auditório adira a uma tese mais ou menos controvertida. São as premissas da argumentação que permitem estabelecer uma comunhão das mentes, ao contar com certos valores e certas hierarquias comuns. Depois, o orador deverá sustentar sua argumentação com os lugares comuns (ou topoi), esquemas de raciocínio compartilhados nos quais são introduzidos seus próprios argumentos - como o lugar do mais ou do menos, ou seja, os lugares da quantidade. No texto de Romain Rolland, "Cumpristes o vosso dever. Mas, e os outros?", isso quer dizer que, se os pequenos devem assumir suas próprias responsabilidades, há uma razão a mais para que os maiores façam isso, ou que, se os jovens cumprem com seu dever em tempos de guerra, ainda com mais razão o devem fazer os dirigentes que os guiam. A 
Linha D'Água (Online), São Paulo, v. 29, n. 2, p. 5-41, dez. 2016

importância primordial das premissas e dos lugares comuns provém de sua função central na dinâmica argumentativa que se estabelece entre o orador e seu auditório.

Segundo Perelman, o orador pode se dirigir a um auditório homogêneo (como quando o célebre nacionalista francês Déroulède fala em uma comemoração da batalha de Champigny aos membros da "Liga dos Patriotas" (AMOSSY, 1997). O auditório pode também ser heterogêneo (no caso de Romain Rolland, quando em 1914 lançou no Le Journal de Genève (O Diário de Genebra) um apelo pela paz destinado a leitores de diversas tendências políticas. O orador pode também buscar um auditório universal. $\mathrm{O}$ desejo de "transcender as particularidades históricas ou locais de forma que todos aceitem as teses defendidas" (PERELMAN, 1970/ 1989, p. 65) leva à noção de uma argumentação capaz de obter a adesão de todo ser com o uso da razão. É necessário restituir à noção controvertida de auditório universal proposta por Perelman suas determinações sociohistóricas. $\mathrm{Na}$ realidade, trata-se da imagem que o orador faz do homem razoável, da sua forma de pensar e de suas premissas, imagem que varia segundo a cultura de quem a constrói. Como afirma Perelman:

Cada cultura, cada indivíduo tem sua própria concepção do auditório universal, e o estudo dessas variações seria muito instrutivo, pois nos faria conhecer o que os homens têm considerado, ao longo da história, real, verdadeiro e objetivamente válido (PERELMAN, 1970/1989, p. 75).

Essa perspectiva rompe com a tradição que define a argumentação como o desdobramento de um raciocínio, a aplicação de uma lógica exterior à relação interpessoal que rege o discurso. Não se trata de minimizar a importância do silogismo ou, de modo mais global, da articulação lógica dos argumentos no trabalho da persuasão. Trata-se de reinserir essas operações em seu âmbito autêntico, isto é, uma troca entre o orador e seu auditório que, obviamente, participa dessa troca, inclusive quando não tem a palavra. Perelman insiste na distância que separa a demonstração da argumentação. Enquanto a demonstração se baseia em axiomas que não procuram o consentimento do destinatário e delas extrai consequências, a argumentação se fundamenta nas premissas que devem ser objeto de um acordo prévio. "Supõe a existência de um contato intelectual" que precisa levar em conta 
Linha D'Água (Online), São Paulo, v. 29, n. 2, p. 5-41, dez. 2016

"as condições psíquicas e sociais sem as quais a argumentação não teria nem objetivo nem efeito" (PERELMAN, 1970/1989, p. 48). Em suma, a argumentação é, por definição, comunicacional e contextual. Sua especificidade consiste em "acionar um raciocínio em uma situação de comunicação” (BRETON, 1996, p. 3).

\subsection{A pragmática}

No sentido que acabamos de descrever, a retórica contemporânea se inclui nas perspectivas interacionais desenvolvidas pela pragmática. De fato, a interação que a retórica situa no nível do discurso é concebida pelos pragmáticos como a realidade fundamental da língua, seguindo Bakhtine/Volochinov. Como afirma Kerbrat -Orecchioni "todo discurso é uma construção coletiva ou uma realização interativa” (1990, p. 13). Disso se deriva que:

[...] na fase de codificação, anterior a toda resposta ou simples interação que emane do destinatário, este se encontra já inscrito no discurso do emissor, às vezes de forma explícita (por meio de marcas de alocução), e sempre implicitamente, já que o emissor leva em conta de forma permanente a imagem que se construiu de seu destinatário e das competências que lhe supõe [...]. Isso implica que, mesmo na ausência do "tu", este exerce um controle permanente sobre o discurso do "eu" (KERBRAT-ORECCHIONI, 1990, p. 14).

Essa perspectiva continua a de Bakhtine/Volochinov, que propõe que:

[...] toda enunciação, inclusive sob a forma estereotipada da escrita, é uma resposta a algo e é constituída como tal. Não é mais que um elo da cadeia dos atos de fala. Toda inscrição prolonga aquelas que a precederam, trava uma polêmica com elas, espera reações ativas de compreensão, antecipa-as etc. (BAKHTINE/ VOLOCHINOV, 1977, p. 105).

Dessa forma, o discurso do orador, se não constitui uma forma de diálogo, é, no entanto, dialógico. Mantém um diálogo com os discursos anteriores que refuta, modifica ou amplia: é a dimensão interdiscursiva. Por sua vez, inclui uma intenção 
Linha D'Água (Online), São Paulo, v. 29, n. 2, p. 5-41, dez. 2016

e se constrói em função de uma certa imagem do interlocutor, mesmo quando este não participa de forma ativa da troca: é a dimensão de inter-relação com o auditório.

Considerando que a linguagem é concebida

[...] como uma atividade que modifica uma situação ao fazer com que o outro reconheça uma intenção pragmática, visto que a enunciação é pensada como um ritual baseado em princípios de cooperação entre os participantes do processo enunciativo, a instância pertinente em matéria de discurso já não será o enunciador, mas o par formado pelo locutor e pelo destinatário [...] (MAINGUENEAU, 1996b).

Como as perspectivas pragmáticas influem no estudo da interação argumentativa, tal como elaborada pela "nova retórica" baseada no ponto de vista aristotélico? De maneira geral, pode-se dizer que elas permitem apreender as instâncias da troca verbal na materialidade do discurso. $\mathrm{O}$ receptor se inscreve nos indícios da alocução e numa base dóxica que competem à análise linguística. O locutor se inscreve nas marcas de enunciação que também são tributárias de um estudo linguístico. Por outro lado, o desdobramento do locutor em várias vozes foi colocada em evidência pela teoria da polifonia elaborada por Ducrot. Portanto, pode-se realizar um estudo preciso do dispositivo enunciativo, colocando-o em relação ao gênero do discurso ao qual pertence. O editorial, a carta aberta, o manifesto, o discurso eleitoral, a alegação, o relato de guerra, todos têm um modelo que regula a inter -relação entre os participantes. Quando "o dispositivo enunciativo [...] relaciona uma organização textual e um entorno social determinado” (MAINGUENEAU, 1996a, p. 8), ultrapassa a análise pragmática propriamente dita e tende à análise do discurso. Efetivamente, na análise do discurso, a linguagem é considerada "a atividade dos sujeitos inscritos em contextos determinados" (MAINGUENEAU, 1996b, p. 28). Em outras palavras, o discurso se encontra determinado por uma situação institucional e social que implica uma distribuição de papéis e uma relação de forças, isto é, as determinações sociais dos participantes são parte integrante da troca argumentativa. De maneira sucinta, e dentro dessa perspectiva, examinaremos o receptor, o locutor e a ancoragem social do dispositivo argumentativo. 
Linha D'Água (Online), São Paulo, v. 29, n. 2, p. 5-41, dez. 2016

\subsubsection{0 alocutário}

A análise interacional convida a vê-lo como uma configuração discursiva. Inscrito no texto, é uma instância concreta que possui marcas linguísticas, indícios de alocução (KERBRAT-ORECCHIONI, 1990, p. 87). Esses indícios, que não são detectados sempre na literalidade do enunciado, podem ser classificados em três categorias: as designações nominais, os pronomes pessoais e os topoi implícitos ou evidências compartilhadas.

\subsubsection{Designações nominais explícitas}

Às vezes, o orador utiliza apelativos que permitem determinar o destinatário de forma eficaz. Assim, Romain Rolland começa Au-dessus de la mêllé com a exclamação: "Oh, juventude heroica do mundo!" Déroulède repreende seu público na abertura da comemoração pelas vítimas de 1870 com o termo "Patriotas!". No entanto, nem sempre se interpela diretamente o público. Ele pode ser designado no texto de forma oblíqua com a forma de um terceiro que é o centro da discussão e a quem, na realidade, se dirige o discurso. Assim, Romain Rolland parece se dirigir aos jovens combatentes de 1914 para denunciar os principais responsáveis pela guerra, os dirigentes e, em particular, as "igrejas" e as "tribunas socialistas". Apesar de evocá-los na terceira pessoa (somente muito mais adiante irá interpelá-los diretamente), é evidente que são os verdadeiros receptores do texto. Através do uso de um tropo comunicacional - no qual, segundo Kerbrat-Orecchioni (1990, p. 21), o verdadeiro receptor não é aquele que é designado diretamente, mas um terceiro ou um destinatário secundário -, o receptor se inscreve no discurso.

As designações nominais podem receber maior ou menor extensão. Às vezes, reduzidas a um nome próprio ou a uma palavra, pode ocorrer também de se converterem em verdadeiras descrições. Essas não se referem necessariamente a uma segunda pessoa do singular, pois podem ser retratos autônomos que se remetam, de forma clara, ao receptor. Quando Romain Rolland faz um chamado "a cada um de nós" para fazer sua mea culpa, já evocou a imagem desse "nós" ao qual solicita pesar e arrependimento. São os "povos que continuam dóceis", que "se resignam”, que 
Linha D'Água (Online), São Paulo, v. 29, n. 2, p. 5-41, dez. 2016

se entregam ao destino e repetem "o velho estribilho dos rebanhos", "que fazem de sua fraqueza um deus...”. Pode-se passar, então, do simples apelativo à designação direta ou indireta e à sua expansão em forma de descrição.

\subsubsection{Pronomes pessoais}

Como corresponde, trata-se em especial da segunda pessoa do singular ou do plural. No fragmento de Romain Rolland, é possível ver que o "vós" pode possuir no mesmo discurso uma pluralidade de referentes. $\mathrm{O}$ escrito se dirige primeiro aos jovens, "Cumpri com vosso dever", e, logo depois, aos dirigentes "Tínheis entre as mãos tais riquezas vivas [...]. Em que as gastais?". O "vós" dos dirigentes se relaciona com os "três maiores povos do Ocidente". Em "Por acaso, nossa civilização é tão sólida que não temeis comprometer seus pilares?”, o receptor pode participar de um "nós" que engloba o locutor: "nossa civilização". Esse "nós" adquire, no caso de Rolland, uma extensão que lhe permite designar o conjunto da população: "Os homens inventaram o destino com a finalidade de lhe atribuir as desordens do universo [...]. Que cada um de nós faça neste momento a sua mea culpa!'. Consequentemente, é importante fazer uma análise precisa dos pronomes pessoais que permitem intervir no auditório, definido como o conjunto daqueles que se quer persuadir, seja sob a forma de um "tu” e de um "vós”, seja de um "nós".

\subsubsection{Evidências compartilhadas}

O discurso determina seu auditório por meio das crenças, das opiniões, dos valores que the atribui explícita ou implicitamente, os quais podem ser formulados de forma clara: por exemplo, Rolland Romain atribui o título de "guardiões de civilização" aos três povos europeus em guerra. Porém, é mais frequente que se inscrevam no texto de forma indireta. Por exemplo, a frase "Ousemos dizer a verdade aos antecessores destes jovens" supõe a supremacia de um valor, a verdade, que merece que se corram riscos para defendê-la. Esse nível de implícito foi estudado pela retórica no capítulo das premissas e dos lugares comuns. Do ponto de vista da pragmática, isso se inscreve, às vezes, nas pressuposições (DUCROT, 1972) e, 
Linha D'Água (Online), São Paulo, v. 29, n. 2, p. 5-41, dez. 2016

outras vezes, nas ideias preconcebidas que subjazem aos enunciados, o que necessita de uma análise linguística com base no que a pragmática e a análise do discurso apresentam como instrumentos (AMOSSY; HERSCHBERG PIERROT, 1997). Em todos os casos em que os indícios de alocução tangíveis (designações e pronomes pessoais) faltam, essa é a única forma de reconstituir o auditório. Com efeito, o texto pode omitir a menção ou a evocação de seu destinatário, mas não pode omitir a inscrição profunda dos valores e das crenças, sem os quais uma comunicação mínima não pode ser estabelecida.

Assim, no fragmento já citado de $A u$-dessus de la mêlée, certas premissas são comuns a todo o auditório em setembro de 1914: a crença no "dever" de obediência militar e de valor, a apreciação admirativa dos jovens combatentes (AMOSSY, 1995). Outras mudam de acordo com o orador que se dirige aos jovens ou aos anciãos, às pessoas do povo ou às elites. De tal forma que nesse discurso dirigido a um auditório heterogêneo podem ser encontrados os diversos níveis de pressuposições e de ideias preconcebidas que se dirigem a cada um dos grupos que são levados em consideração.

Também podem ser distinguidas as estratégias empregadas para cada um desses auditórios. $\mathrm{O}$ texto usa diferentes meios para fazer que o povo compreenda que está sendo sacrificado por dirigentes irresponsáveis e que deve retomar as rédeas de seu destino. Mobiliza outros meios para responsabilizar as elites dirigentes e thes recordar sua missão civilizadora. A perspectiva pragmática oferece um conjunto de instrumentos que permitem analisar com precisão a base dóxica do discurso.

\subsubsection{O locutor}

O locutor se inscreve no discurso com marcas enunciativas concretas: pronomes pessoais, dêiticos etc. cuja análise exige aplicar uma linguística da enunciação. Por outro lado, a perspectiva enunciativa se articula sobre a noção retórica do ethos ou imagem do orador. Nos trabalhos de Ducrot (1984/1986, p. 204-205) e, sobretudo, de Maingueneau (1996a, p. 137-154), considera-se o que o orador dá a ver de sua própria pessoa não apenas por aquilo que ele diz de si mesmo, mas também e essencialmente por sua forma de se expressar. No quadro da pragmática, o ethos afeta 
Linha D'Água (Online), São Paulo, v. 29, n. 2, p. 5-41, dez. 2016

o locutor no modo como ele se constrói no seu discurso e não na pessoa empírica do indivíduo. Sua palavra permite reconstruir um caráter e uma corporalidade que "se apoiam em alguns estereótipos valorizados ou desvalorizados na comunidade em que se produz a enunciação" (MAINGUENEAU, 1996b, p. 40; AMOSSY, 1998). Em Au-dessus de la mêlée, o locutor não se incomoda em se apresentar, mas usa a apóstrofe e a asserção, o ritmo e as perguntas retóricas, a primeira pessoa do plural e o imperativo, de modo que constrói no discurso a imagem de uma pessoa suscetível de influenciar o público (AMOSSY, 1995, p. 60-61). Pelo contrário, na Carta aos camponeses, de Giono (1978), o ethos, já marcado no estilo, está reforçado pelas afirmações categóricas sobre a postura do locutor: "Eu digo as verdades como as penso, mesmo se elas lhes forem desagradáveis [...] Não procuro agradar...” (GIONO, 1978, p. 205).

Em outro nível, a teoria da polifonia proposta por Ducrot redefine a instância da enunciação. Ao longo de seus avatares no final dos anos setenta e até nossos dias, essa teoria foi construída com base em um mesmo princípio: o questionamento da unicidade do falante. Essa unicidade, que pode ser resumida na fórmula "um enunciado, um sujeito", ocorre para abrir caminho a uma multiplicidade de instâncias designadas por diversos termos. Ducrot distingue entre, por um lado, o ser empírico, o indivíduo que na realidade pronuncia o enunciado (1) e que é o único situado no mundo, e, por outro lado, o "locutor" (L) e o "enunciador" (E), que são seres de discurso ou, segundo a formulação de Reboul, "seres teóricos [...] que não se encarnam” (1992, p. 326). O locutor (L) que assume a responsabilidade do enunciado Pedro não é boa gente "põe assim em cena [...] um enunciador E1 que assevera que Pedro não é amável, e outro, E2, com quem normalmente é homologado a L, que se opõe a E1” (DUCROT, 1984/1986, p. 219). No enunciado de Romain Rolland: "Cumpris com vosso dever", há várias entidades. Distingue-se a pessoa empírica, o homem Romain Rolland, o famoso escritor francês que se encontra na Suíça onde em 1914 faz um apelo pela paz no Journal de Genève; e o locutor L, o "eu" que se deduz pela segunda pessoa à qual se dirige ("vós"), entidade discursiva que assume a responsabilidade do enunciado. $O$ locutor põe em cena um enunciador $\mathrm{E}$ que é o rumor público, a voz do consenso que se expressa 
Linha D'Água (Online), São Paulo, v. 29, n. 2, p. 5-41, dez. 2016

mediante um clichê que na época gozava de um grande reconhecimento ("cumprir com o seu dever").

$\mathrm{L}$, por sua vez, retoma a palavra e o ponto de vista de $\mathrm{E}$ para relançar melhor o debate desde esse ponto: "Cumpris com vosso dever. Mas, e os outros?". Essa descrição parcial, que não substitui a análise, apenas pretende ilustrar o tema da polifonia (o orador não é um só) e do dialogismo (a palavra do Outro está presente na do eu) em uma situação argumentativa.

A polifonia, como a entende Ducrot, não goza de unanimidade entre os pragmáticos, que lhe fazem várias críticas. Se há algum interesse no âmbito da análise argumentativa é porque esta permite descentrar o modelo retórico reformulado pela nova retórica de Perelman, que poderia ser definido como "uma argumentação, um sujeito". De fato, na visão tradicional, o orador é uma instância unificada e autônoma (uma voz única) que transmite uma mensagem clara graças ao domínio dos meios discursivos de que dispõe. Na perspectiva dialógica e polifônica, a instância do orador, múltipla e complexa, está constituída por várias vozes.

\subsubsection{A ancoragem social do dispositivo enunciativo}

A articulação do modelo retórico tradicional com as perspectivas dialógicas e interacionais da pragmática não só permite apreender a inscrição da interação argumentativa na língua. Também permite colocar em evidência sua dimensão social que, inscrita no dispositivo enunciativo, aparece na posição que ocupa cada um dos participantes em função da distribuição dos papeis que autorizam: a) um gênero de discurso instituído, b) uma situação institucional particular, ou c) um imaginário social.

Com efeito, a interação do locutor e do receptor se molda pelo gênero do discurso selecionado, que depende das possibilidades da época, isto é, da gama e da hierarquia dos discursos que uma cultura propõe em um momento determinado de sua história. Maingueneau (1996b, p. 44) aponta que "se tende [...] a empregar gêneros discursivos para dispositivos de comunicação definidos social e historicamente: a notícia, o editorial, a consulta médica, o interrogatório policial...”. $\mathrm{Na}$ política contemporânea, um discurso em um comício político se diferencia de um 
Linha D'Água (Online), São Paulo, v. 29, n. 2, p. 5-41, dez. 2016

discurso eleitoral na televisão. $\mathrm{O}$ gênero da oração fúnebre no século XVII se distingue da comemoração dos mortos pela pátria, em moda depois da guerra de 1870, que supõe um dispositivo modelo que não é o mesmo que o do editorial ou o da discussão em um círculo de amigos. Pode-se afirmar, de acordo com Maingueneau, que "o gênero discursivo se apresenta como [...] uma atividade social de um tipo particular, que se exerce em circunstâncias adaptadas, com protagonistas qualificados e de uma forma apropriada." (MAINGUENEAU, 1993, p. 67).

Retomemos $A$ u-dessus de la mêlée: primeiro o texto foi publicado no Journal de Genève como um artigo de opinião que protesta contra o estado de violência que os dirigentes não souberam e nem quiseram enfrentar. À sua maneira, Romain Rolland lançou seu Eu acuso contra os dirigentes e as elites que ele responsabiliza pelos transtornos sociais. $\mathrm{E}$ faz isso adotando um gênero discursivo reconhecido na sociedade da época que implica a distribuição prévia de alguns papeis. Um artista já reconhecido, comprometido com os assuntos políticos, denuncia com toda a clareza seus abusos e seus erros. Coloca-se como porta-voz da Verdade que se dirige à nação inteira, mesmo que se dirija a alguns destinatários determinados.

Essa é a postura que adota o locutor para lançar um chamado contra uma guerra que ameaça ser devastadora. A postura do locutor implicado pelo gênero é possível, fora do discurso, pela posição institucional que possui a pessoa empírica no setor intelectual da época. Como o autor de Jean-Christophe goza de um grande reconhecimento e é considerado como um guia espiritual, um poeta da reconciliação franco-alemã e dos valores pacifistas, pode lançar um chamado que ressoará em toda a França e que será o centro de polêmicas acaloradas. Convergimos, nesse sentido, na análise sociológica em termos de campos como proposto por Bourdieu. O modo de intervenção do escritor e sua autoridade correspondem à sua posição em um dado estado do campo literário. Isto é, a interação argumentativa depende também de restrições exteriores ao discurso: o espaço institucional no qual se inscreve o estatuto e a posição dos participantes, as normas de interação que esse âmbito autoriza ou exclui.

Dessa forma, desemboca-se no tema da autoridade do locutor, que não deriva apenas do papel que lhe confere o gênero do discurso adotado e a posição do escritor no campo, mas também do ethos que constrói em seu discurso, o qual é tributário de 
Linha D'Água (Online), São Paulo, v. 29, n. 2, p. 5-41, dez. 2016

um sistema de representações sociais, de um imaginário social. De fato, a imagem do escritor dissidente, do intelectual que diverge do consenso, da verdade oficial, corresponde, na França de princípios do século, a uma cenografia familiar. No entanto, o que contribui para afirmar a autoridade do orador se converteu em problema, quando a guerra começou e, ainda mais, porque optou pela Suíça para publicar sua convocação no momento dos combates. Isso fez de Romain Rolland, aos olhos de um bom número de franceses, um desertor e um germanófilo traidor de sua prática. $\mathrm{O}$ "eu" que toma a palavra no texto se encontra, assim, confrontado com imagens prévias (a do intelectual de esquerda dissidente e valoroso, mas também a do antipatriota) que the impõem mobilizá-las ou corrigi-las em seu proveito.

No discurso, ele põe em jogo esses dados sobre a situação e fatos sociais diversos para seu apelo pela paz. Em função desses parâmetros, estabelece-se a interação com o auditório contemporâneo. Certamente, acrescenta-se a tudo isso o caráter social do discurso posto em troca entre os participantes da interação argumentativa. A perspectiva dialógica citada mais acima mostra que a palavra do orador se vê necessariamente influenciada, às vezes sem saber, pela palavra do Outro, pelo que se diz ou pelo que se escreve em uma determinada sociedade. Do mesmo modo, na polifonia, segundo Ducrot, o locutor devaneia um discurso em que se deixaram ouvir outras vozes que expressam outros pontos de vista em e sobre uma situação concreta. Disso, deduz-se que todo discurso argumentativo é interdiscursivo e, portanto, está ancorado em um contexto sociohistórico determinado, de tal forma que o estudo do dispositivo enunciativo se revela tributário da interdiscursividade, da polifonia, dos gêneros do discurso, da situação institucional e do imaginário social. No cruzamento da retórica e da pragmática, a argumentação revela sua dimensão social. Podese considerar então que a análise argumentativa é um ramo da análise do discurso, globalmente definida pela "articulação do linguístico e do social, do discursivo e do interdiscursivo, e por levar em conta as restrições genéricas e institucionais que regem o discurso" (AMOSSY; HERSCHBERG-PIERROT, 1997, p. 106). 
Linha D'Água (Online), São Paulo, v. 29, n. 2, p. 5-41, dez. 2016

\section{Argumentação e Narratologia: o dispositivo enunciativo do relato de ficção}

Quando passamos ao relato, a análise retórica e pragmática da interação argumentativa deve ser realizada com base em um estudo narratológico. Para apreender o relato de ficção em sua complexidade, é conveniente adaptar o modelo básico da interação argumentativa às necessidades da narração. Em outras palavras, é necessário levar em conta a especificidade do seu dispositivo enunciativo, objeto de múltiplas análises por parte dos que estudaram a diferença entre as diversas instâncias da narração, o tema das vozes e o da focalização. Integrado mais recentemente à teoria do relato, o destinatário tem sido analisado como narratário e tem sido objeto de reflexões mais profundas nos estudos das teorias da leitura desenvolvidas a partir de perspectivas diversas.

Contudo, os instrumentos de análise tomados da poética e das teorias da leitura serão reintegrados já aqui no quadro da interação concebida pela pragmática e pela retórica. Em outros termos, o relato não será considerado como um texto fechado, um objeto autônomo do qual se devem descrever as estruturas internas, mas como um discurso que comporta uma direção, mesmo que seja implícita. Inclusive quando se considera que uma obra literária não implica troca, porque não permite alternância entre os coenunciadores (cf. MAINGUENEAU, 1993, p. 31), é possível situá-la em uma perspectiva comunicacional e dialógica. Na realidade, a escrita de ficção, como todo discurso, prolonga "as inscrições que lhe precederam, estabelece uma polêmica com elas, espera reações ativas de compreensão, as antecipa” (BAKHTINE, 1977, p. 105). Alguém conta uma história a alguém, uma instância narradora mais ou menos complexa se dirige a uma instância de recepção mais ou menos explícita. Como afirma Eco, "generalizar um texto significa colocar em prática uma estratégia da qual formam parte as previsões dos movimentos do outro" (ECO, 1985, p. 70). A organização da estratégia textual precisa levar em conta uma série de competências que compreendem um saber enciclopédico e uma reserva de roteiros compartilhados. Assim, estabelece-se o que o autor de Lector in Fabula chama de "cooperação textual".

Com frequência, o enfoque interacional do relato é difícil de perceber porque numerosos textos estão relatados por um narrador em terceira pessoa que parece 
Linha D'Água (Online), São Paulo, v. 29, n. 2, p. 5-41, dez. 2016

ausente da obra. Anônimo e transparente, não deixa nenhuma marca clara. Além disso, as narrações que tendem a fazer esquecer sua fonte de enunciação apagam com precaução, no mesmo ato, as marcas do narrador. Esse tipo de relato que parece "se contar sozinho" contribuiu, e não pouco, para velar o fato de que em nenhum caso pode haver narração sem dispositivo enunciativo. $\mathrm{Na}$ teoria, essa confusão pôde ser mantida por uma aplicação um tanto abusiva das categorias de Benveniste que diferencia o discurso - que utiliza o sistema da pessoa (eu-tu) e as marcas gramaticais correspondentes (tempos, dêiticos...) - do relato, que é construído com base no sistema da não-pessoa (a terceira pessoa) e as marcas gramaticais correspondentes. Ao generalizar essa descrição de duas formas possíveis de utilização da linguagem, os estudos literários esqueceram, algumas vezes, que toda fala consiste, em última instância, em uma interlocução. Procederam como se pudesse não existir direção no texto, como se um discurso romanesco pudesse se desdobrar sem se dirigir a ninguém. Mas é precisamente essa uma das especificidades do relato: o fato de que se possa estabelecer uma interação que não comporte nenhuma marca explícita nem de enunciação nem de alocuções.

Como pode existir uma dinâmica interacional entre duas instâncias vazias, entre dois ausentes? O que poderia parecer absurdo no plano da comunicação cotidiana se revela um caso comum no relato de ficção. Juntamente aos relatos pessoais em primeira pessoa, encontram-se modelos romanescos que dão prioridade ao narrador impessoal, invisível, ausente, que permite o relato em terceira pessoa. Mas não por ser uma terceira pessoa anônima: o narrador se envolve menos no discurso no qual numerosas indicações permitem reconstruir sua imagem e sua relação com o narratário. Ao aparecer como uma não-pessoa (um ele), é frequentemente (e de forma abusiva) identificada com o autor cujo nome aparece na capa. Quanto à figura do destinatário, as modalidades em que ele se inscreve no texto e suas funções na interação não diferem em nada das que caracterizam os relatos em primeira pessoa. No relato, a interação entre dois "ele" pode ser reconstruída da mesma forma que aquela que se estabelece entre o "eu" e o "tu/vós". Isso é mostrado pela análise do texto de Roger Martin du Gard que é proposto mais abaixo, no qual tanto o narrador quanto o narratário estão na terceira pessoa e permitem uma interação dotada de uma lógica diferente da que se desenvolve no plano das 
Linha D'Água (Online), São Paulo, v. 29, n. 2, p. 5-41, dez. 2016

personagens. Esse aspecto também é esclarecido pela análise apresentada por Viala (1993) de dois romances curtos de Jean-Marie Gustave Le Clézio: um deles, Villa Aurora, está narrado em primeira pessoa, enquanto que o outro, La grande vie, está em terceira pessoa. A análise do dispositivo enunciativo desses dois relatos mostra que a postura do locutor e sua relação com o receptor é semelhante; ambos podem se resumir, nos termos de Viala, na simpatia pelos personagens fracos e perdedores, e a conivência com o leitor (VIALA, 1993).

O relato de ficção proporciona um caso desconhecido na prática comum da linguagem, a interação entre duas instâncias da terceira pessoa.

Para entender o dispositivo enunciativo da argumentação na situação de ficção, retomaremos as classificações da narratologia e as distinções tradicionais estabelecidas entre autor ${ }^{7}$, narrador e personagem ${ }^{8}$. A situação se complica quando o relato apela a um narrador metadiegético (situado em um relato marcado) e intradiegético (situado no relato fechado) (GENETTE, 1972). O desdobramento

7 No que se refere ao autor, daquele que quase não trataremos neste artigo, é necessário diferenciar a imagem do autor que se desprende do texto - que Jean-Michel Adam denomina "o autor abstrato" (de acordo com Lintvelt) - do autor concreto, ou pessoa do escritor (ADAM, 1994, p. 223-224). Essa diferenciação confirma a que realizamos ao falar da ancoragem social do dispositivo enunciativo: de um lado, está a imagem do autor (que provém do imaginário social e se une ao nome do autor que se apresenta na capa) e, de outro lado, a pessoa do escritor (que ocupa uma posição no campo literário e intelectual.

8 Recordemos que, em seu modelo de polifonia, Ducrot propõe um paralelismo entre locutor/ narrador e autor sujeito falante empírico: "O correlato do locutor é o narrador que Genette opõe ao autor da mesma maneira que eu oponho o locutor ao sujeito falante empírico, isto é, ao produtor efetivo do enunciado" (1984, p. 21 1). Além disso, o narrador estaria para o personagem como o locutor está para o enunciador. Ducrot não se refere tanto ao caos no qual as vozes estão bem diferenciadas, isto é, quando o personagem fala no discurso direto, mas sim quando o narrador fala a partir de um ponto de vista que não é o seu próprio, no momento em que ele se expressa. Como afirma: "O locutor fala no sentido em que o narrador conta, isto é, aparece como a fonte de um discurso. Mas as atitudes expressas nesse discurso podem ser atribuídas a enunciadores dos quais ele se distancia, tais como os pontos de vista manifestados no relato, que podem ser os dos sujeitos de consciência alheios ao narrador" (1984, p. 231). A analogia nos parece de pouca ajuda, pois tende a efetuar uma encenação concreta e, de certo modo, imediatamente perceptível do fenômeno da polifonia. Mas, ao fazê-lo, confunde a polifonia inerente à enunciação com a construção narratológica. Trata-se de uma analogia que procura a exemplificação, na qual a narratologia permite esclarecer a análise pragmática, mas não vice-versa. Seria necessário sair da analogia para ver como a teoria da polifonia permite repensar o dispositivo narrativo. 
Linha D'Água (Online), São Paulo, v. 29, n. 2, p. 5-41, dez. 2016

do sujeito da enunciação é constitutivo do relato. A imbricação de vozes no texto narrativo é um fenômeno que desempenha um papel importante na argumentação que nele se desenvolve. Propõe um modelo de enunciação que compreende uma instância no mínimo tripla: autor/narrador/personagem, suscetível a numerosas variantes. Ainda que cada texto conserve a liberdade de propor suas próprias variantes (como é o caso do relato em segunda pessoa de Modificação, de Michel Buton), ele se ajusta a um modelo básico que responde às coerções do gênero: o diário íntimo, a autobiografia, o testemunho, a parábola etc.; ou responde aos imperativos de uma estética: o romance naturalista, a escrita surrealista, le nouveau roman...

No eixo da recepção, a análise argumentativa do relato de ficção pode fazer suas as distinções entre o público real e o leitor no texto. Distingue-se entre o narratário (PRINCE, 1973) que é o destinatário ao que se dirige o narrador, seja meta ou intradiegético, confundido com frequência com o leitor implícito de Iser (1975) e o leitor modelo de Eco (1985). Essa instância reconhecível no discurso remete, por sua vez, ao leitor suposto ou o tipo de leitor que o autor imagina para sua obra em função dos leitores possíveis em sua época. Assim, o auditório construído pelo discurso argumentativo no relato de ficção se coloca em diversos níveis que correspondem aos diferentes níveis da enunciação. Vai desde o personagem a quem se dirige um protagonista até o leitor possível que o autor levou em conta, passando pelo narratário a quem se dirige o discurso do narrador principal. Mesmo que este enfoque coincida com o das teorias da leitura, das quais toma emprestada sua terminologia de forma seletiva, ele se diferencia delas porque estuda o impacto do discurso, ou seja, as estratégias que se atualizam para agir sobre o público. Mais que examinar o ato da leitura como ativação de significações ou como experiência estética, como nos estudos de semiótica, da teoria do efeito estético ou da estética da recepção, a análise argumentativa se interessa principalmente pela maneira como a imagem do auditório modela um discurso que procura orientar a visão e influenciar seu comportamento.

Mas, o que acontece com o público real? Não só o tipo do leitor previsto não corresponde sempre aos consumidores reais, mas o texto literário se caracteriza por propor uma leitura diferenciada por definição. E não apenas porque esse é o destino do escrito (por oposição ao oral), mas também porque, diferentemente do 
Linha D'Água (Online), São Paulo, v. 29, n. 2, p. 5-41, dez. 2016

jornal, por exemplo, trata-se de uma comunicação que perdura. Leem leitores que pertencem a outras épocas, ou a outras culturas, que o narrador não pode inscrever em seu texto e que o autor não pode prever. Disso resultam leituras diferenciadas em que a interação não se cumpre necessariamente sobre a base da doxa ${ }^{9}$ compartilhada, a qual permite uma programação mínima. Essa dimensão do texto literário cria problemas de relação entre o auditório construído pelo orador e o auditório construído pelo orador e o auditório empírico tal como apresenta Perelman, que insistia sobre a necessidade de construir uma imagem do interlocutor a mais próxima possível da realidade porque do contrário sua empresa de persuasão poderia fracassar. A dimensão argumentativa de um texto pode mudar de forma inopinada quando é decifrada pelos leitores dotados de outro saber enciclopédico e de outras crenças e topoi que os do locutor; ou simplesmente quando o contexto da enunciação mudou. Entretanto, não deixa sem validade a dimensão argumentativa do texto, mas a modifica e com frequência inesperada. No entanto, este tipo de interação e sua lógica particular não podem ser considerados mais do que por uma estética da recepção que se centre nas diferentes leituras de um texto realizadas em diferentes épocas (JAUSS, 1978), ou também por um estudo empírico que se realize mediante levantamentos como os que se realizam atualmente nas ciências cognitivas. Mas, esse empreendimento ultrapassa o estudo argumentativo propriamente dito, já que escapa para a análise do discurso: estuda os efeitos da persuasão mais do que a interação argumentativa inscrita no discurso.

Retomemos, então, o dispositivo enunciativo do relato de ficção e sua análise argumentativa à luz do esquema básico da retórica e da pragmática, reformulada agora pela narratologia. A interação entre o locutor e o destinatário se desdobra em cada extremo da cadeia, pelo menos, em duas instâncias simultâneas: a dos personagens e a do narrador/narratário.

$L /$ enunciadores $1,2 \ldots$

DESTINATÁRIO//receptor empirico.

9 Cf. artigo de Plantin

AMOSSY, R. A interação argumentativa no discurso literário: da literatura das ideias ao relato de ficção 
O esquema ordinário da interação argumentativa passa pelo dialogismo e pela polifonia descrita anteriormente. O locutor e o destinatário compartilham uma base dóxica imprescindível para o dinamismo interacional e se situam em um contexto da enunciação muito concreto que compreende a situação, o âmbito institucional e o gênero do discurso. $\mathrm{O}$ relato de ficção substitui este modelo por um esquema desdobrado e hierarquizado que compreende como elementos básicos: o autor (A), o narrador (Ndor), o personagem (P), o narratário (Nrio), o leitor suposto (L) - e, no fim da cadeia, o leitor empírico. O narrador pode se dividir em meta ou intradiegéticos no caso de relatos intercalados (Ndores 2, 3...), que implicaria a mesma subdivisão no caso dos narratários. Disso se deriva o seguinte esquema global:

$$
A / N \text { dor }[\text { Ndores } 2,3 \ldots] / P \quad P / \text { Nrio }[\text { Nrio } 2,3 \ldots] / L
$$

Este esquema está demarcado pelas instâncias do escritor como ser no mundo e como posição no campo literário, e do receptor empírico, que correspondem às instâncias: locutor como ser no mundo e receptor empírico.

Nessa perspectiva, a argumentação do relato se desenvolve simultaneamente em diversos planos. Os personagens se comunicam entre eles e se entregam a atividades de persuasão mais ou menos confessadas, que vão desde o discurso pronunciado por um protagonista para que seus interlocutores adiram a sua tese (como no exemplo de Os Thibault apresentado adiante), até o diálogo anódino em que se efetua uma confrontação ou a troca de pontos de vista (como no início de O Coronel Chabert). Atrás dos personagens se perfila um narrador em primeira ou terceira pessoa que se dirige a um narratário designado ou implícito. A interação entre dois ou mais personagens fica, assim, demarcada por uma interação que nem se situa no mesmo plano nem comporta necessariamente os mesmos objetivos. A isso se acrescenta o fato de que, nos numerosos textos que apresentam narrações uma dentro da outra, em que um narrador metadiegético alterna com um narrador intradiegético, os objetivos da persuasão do relato marcado e do relato incerto não se solapam forçosamente. No caso da $A$ Pele de zapa, de Balzac, o relato do narrador em terceira pessoa se vê interrompido por uma longa narração de Raphaël, que 
Linha D'Água (Online), São Paulo, v. 29, n. 2, p. 5-41, dez. 2016

conta sua vida a seu amigo em primeira pessoa. A interação realizada entre o relato pessoal e o que se constrói no relato fantástico que lhe serve de base pertencem a gêneros diferentes e apresentam objetivos argumentativos divergentes (AMOSSY, 1979). Por último, o narrador remete a uma imagem do autor, a que o público pode criar e que exerce influência sobre esse público. Reciprocamente, o autor constrói uma imagem de seu suposto leitor, que influencia suas escolhas argumentativas. Complicado por conta do procedimento de desdobramento, o dispositivo enunciativo básico se coloca em diversos planos que se superpõem e articulam argumentações diferenciadas.

\section{Análise argumentativa de um exemplo romanesco: 0 discurso de Jacques Thibault no comício socialista de 30 de agosto de 1914 em O verão de 1914}

Um exemplo concreto mostrará a natureza e a complexidade do dispositivo enunciativo característico do relato de ficção. Frente ao discurso pacifista de Romain Rolland publicado em 1914 no Journal de Genève, examinaremos, de forma breve, em O Verão de 1914, de Roger Martin du Gard (1936/1964), a arenga do protagonista Jacques Thibault contra a mobilização iminente.

O comício político constitui um gênero de discurso que oferece à argumentação uma base e uma distribuição de papéis preestabelecidos. Como membro de um partido, o orador não precisa conhecer pessoalmente seus ouvintes para se adaptar a eles. $\mathrm{O}$ auditório representa um grupo coerente que compartilha sua ideologia e seus objetivos. Se ele toma a palavra em uma assembleia que comunga das mesmas ideias e dos mesmos ideais, é, às vezes, para reforçar os valores e uma linha de ação, e, outras, para intervir em uma dissenção quando diversas opções são possíveis sobre a base de valores comuns. Isso é o que acontece no comício socialista de $30 \mathrm{de}$ julho de 1914. A reunião é celebrada em um momento em que reina o desconcerto por ausência de uma ordem clara sobre a atitude que devem adotar frente à mobilização iminente. Jacques Thibault, militante pacifista, tem diante de si um auditório homogêneo familiarizado com o discurso socialista contra a guerra, porém desamparado com o retorno do patriotismo republicano. Trata-se, portanto, de apostar 
Linha D'Água (Online), São Paulo, v. 29, n. 2, p. 5-41, dez. 2016

nos pontos de acordo prévios para levá-los até posições pacifistas claras. Nesse sentido, o orador faz escutar a postura de seu partido exemplificada por Jean Jaurés. Retoma e modula as teses afirmadas em numerosas reuniões socialistas nacionais e internacionais. Nos termos de Ducrot, o locutor põe em cena o discurso de um enunciador E1 que, por sua vez, faz deste o seu. Se recorda seu conteúdo, a saber, a tese bem conhecida da greve geral no caso de mobilização obrigatória, é para se opor à tendência crescente de se comprometer com a defesa da pátria "ameaçada".

Os indícios de alocução que designam um auditório homogêneo são claros. Com o termo "Camaradas!", o orador dirige-se primeiramente a seu auditório com o pronome "nós". Marca a relação de pertencimento a um grupo, no qual ele se inclui, de seres ameaçados ("A guerra! Está sobre nós!" [MARTIN DU GARD, 1964, p. 157]), soldados enviados para a frente ("E estes soldados, com os quais conta o capitalismo para sua obra de ganâncias e de morte, somos nós!” [op. cit., p. 158]), homens do povo ("Hoje em dia a paz está nas mãos dos povos! Em nossas mãos!" [op. cit., p. 160]), e, por último, franceses ("E ao declarar a greve, nós, os franceses, matamos dois coelhos com uma cajadada só" [op. cit., p. 160]).

O jogo dos pronomes pessoais que pontuam o texto é mais complexo. Assim, o "vós" é de diferentes ordens. Por um lado, é paralelo ao "nós”. Há também o "vós" ameaçado: "Antes de um mês, todos vós que estais aqui esta noite podeis ser mortos no 'massacre'!..." (MARTIN DU GARD, 1964, p. 157); está o "vós franceses" na frente da rejeição: "Vós mesmos! Nós, os franceses, nos negando a combater!" (op. cit., p. 160). Porém, o orador apresenta também ao seu público, muito diretamente, uma dupla imagem de vítima e de culpado, na qual não se inclui. Esses homens serão vítimas, porque lhes é imposta uma guerra que não desejam: "A guerra! Vós não a quereis, mas 'eles' sim a querem. E vos imporão! Sereis suas vítimas!” (op. cit., p. 157). No entanto, o povo sacrificado é responsabilizado imediatamente: "Mas também os culpados! Porque somente de vós depende impedir esta guerra...” (op. cit., p. 157). O discurso joga com essa alternância do "vós” enviado à morte e do "vós" que recusa a guerra, do "vós" vítima e do "vós" culpado. Junto aos "vós”, há, por um lado, o "eles", o impessoal ("Vos dizem" [op. cit., p. 158]), o Outro, representado pelo "capitalismo, [...] a força do dinheiro e dos traficantes de armas" (op. cit., p. 158), os governos e os "homens de Estado", "chanceleres”, “soberanos" (op. 
cit., p. 160); por outro lado, o "eu" que solicita ser escutado e seguido: "Olhais-me? Todos vós vos perguntais: 'O que fazer?' E para isso viestes aqui esta noite... Pois eu vou dizê-lo!” (op. cit., p. 157). Nessa distribuição de papéis, o auditório apresentado como a vítima e o inimigo "eles", figura maléfica do oponente, é o auditório privilegiado do "eu" considerado como coadjuvante, ou melhor, como conselheiro e guia. O "eu" revela a verdade, convida à reflexão ("Compreendei bem isto" [op. cit., p. 160], "refleti” [op. cit., p. 160], "pensai-o" [op. cit., p. 161]) e incita à ação (“O que fazer?, vos direis. Não nos deixaremos dominar!...”).

Notamos como o orador desenha em seu discurso a figura de um auditório homogêneo, unificado em todos seus aspectos, movido pelos mesmos interesses e capaz de atuar como um só homem. Pode fazê-lo de forma ainda mais fácil quando se fundamenta em um acordo prévio no qual se refere aos elementos essenciais da sua argumentação. Não se trata apenas da inquietude legítima que faz pesar sobre todos a ameaça de um conflagração, mas também dos princípios socialistas que subjazem à atitude do auditório a respeito da guerra. Jacques Thibault evoca a luta de classes, o capitalismo promotor das guerras, a união dos trabalhadores, a arma da greve contra a mobilização. Pode basear-se nesses princípios porque os tem compreendidos, assimilados e fundidos no corpo de sua doutrina. Portanto, podem ser lançados imediatamente ao tema principal sem necessidade de assegurar as premissas.

O que acontece com o narrador? O que ele dá para ler ao narratário, de certo modo, por trás das palavras da personagem? Se a argumentação de Jacques é própria do discurso do comício, a do narrador se ajusta a um gênero do discurso reconhecível na tradição literária. Transparente e anônimo, o narrador em terceira pessoa de Roger Martin du Gard obedece à regra do romance histórico, que é também a do romance realista a que pertence Os Thibault. Quem fala não precisa de determinações, uma vez que constitui uma voz desencarnada que conta o real e devaneia, com toda objetividade, o fio da história social e privada. Ao contrário de Tolstoi ou de Zola, o narrador de Os Thibault não faz escutar a voz anônima do sábio ou do historiador chamados para difundir um saber unívoco. Recusa não somente os comentários oniscientes, mas também as perspectivas globais e os enfoques de conjunto. É, 
Linha D'Água (Online), São Paulo, v. 29, n. 2, p. 5-41, dez. 2016

antes, como já se destacou, o observador que mostra, refere, cita e detalha. Propõese a encenar o comício socialista e o discurso de Jacques em prol da paz.

Quanto aos comentários explícitos, ele parece se contentar em fazer algumas marcações cênicas mais ou menos elaboradas. Esse é o modelo que adapta o dispositivo enunciativo que regula a interação do narrador e do narratário.

Agora, essa encenação teatral de uma palavra que busca a eficácia imediata também questiona no texto os limites ao mesmo tempo pragmáticos e éticos do discurso de Jacques. Com efeito, ainda que as apresentações do narrador pareçam, a princípio, inocentes, sobretudo, porque se apresentam como simples $r$, elas estão cheias de conteúdo quando são examinadas com atenção. Destacam a embriaguez suscitada no orador pela arenga pública e sugerem, assim, o delicado problema da demagogia. A dramatização do discurso de Jacques suscita o problema da responsabilidade do orador com relação àqueles os quais incita à ação: "Subitamente tudo se tremeu. Uma vertigem repentina... Como a luz de um relâmpago, apareceu-lhe toda sua responsabilidade. Havia feito bem em fazer uso da palavra? Estava seguro de possuir a verdade?... Durante um minuto, assaltado pelos escrúpulos, esteve indefeso contra um total desalento" (MARTIN DU GARD, 1964, p. 158). No entanto, essa pergunta, tão legítima em uma situação tão grave, desaparece quando um movimento de massas se produz, os militantes dispostos a partir retrocedem para a sala assim "como a lima do ferro é atraída pelo ímã”. O narrador descreve a forma em que o tribunal público se deixa levar pela relação com a multidão que apaga nele a dúvida: "Em um abrir e fechar de olhos, sua angústia cedeu e se desvaneceu sem deixar o menor rastro. E, de novo, tudo o que pensava, tudo o que queria dizer a estes homens cuja muda interrogação subia até ele, lhe pareceu claro e indiscutível" (op. cit., p. 158). A imagem que Jacques constrói para si do auditório lhe devolve, em um jogo de espelhos, sua própria imagem ampliada. Seu discurso se move por uma vontade de poder que contribui para reforçar uma convicção livre de qualquer dúvida: "De todas estas caras, das quais não se distinguia nenhuma com precisão, brotava um chamado que lhe conferia uma importância emocionante e imerecida, mas que, ao mesmo tempo, multiplicava a violência de suas convicções” (op. cit., p. 159). E um pouco mais adiante: "Estava consciente de sua força”. 
O discurso do narrador revela a influência mútua que exercem um sobre o outro, o orador e o auditório, ao desnudar as engrenagens secretas do mecanismo de eloquência política. Por um lado, um locutor ao qual o público devolve a imagem ampliada que desempenha a função de verdade: a partir desse momento, já não se preocupa nem em comprovar nem sequer em refletir. Sua palavra não abre um espaço de deliberação e de debate, tende a se confundir com o exercício do poder: o homem público induz à ação aqueles a quem ele dirige a palavra na embriaguez e procura pelo sentimento de seu próprio poder. Por outro lado, para fazer reagir a multidão, o orador deve proporcionar-lhes um espelho complacente de sua força. Persuadir o auditório de seu poder de ação em razão de sua massa não é arriscar-se a predispô-lo e a armá-lo para uma violência que nem sempre é possível canalizar? O problema dos limites éticos da argumentação politica surge com tanta força que a causa do pacifismo não pode ser condenada, em Os Thibault, sobre bases morais. No caso da tribuna socialista, também existe dinamismo demagógico que não difere verdadeiramente do que caracteriza a argumentação nacionalista de um Déroulède. A direita e a esquerda vêm a coincidir de certo modo. A complexidade de se questionar sobre a validade ética da argumentação é ainda maior porque é suscitada mais pela atuação oratória do que pela personalidade de Jacques. De fato, em situações urgentes nas quais o efeito do discurso deve ser imediato, nas quais se trata de incitar uma eleição e uma ação que não podem demorar, os riscos de cair na demagogia são grandes. Então, como diferenciar a demagogia culpável da argumentação legítima? É a pergunta capital e, sem dúvida, espinhosa da ética na retórica, que sugere, sem pretensão de resposta, o discurso do narrador.

A segunda questão que o narrador suscita contempla os limites da eficácia que pode possuir um contradiscurso, um discurso assumido por um indivíduo que vai à contracorrente do consenso de forma deliberada. $\mathrm{O}$ momento escolhido é muito propício para essa exploração. A cena se situa em 30 de julho de 1914, na véspera do assassinato de Jaurès e da mobilização geral. A confusão é grande no comício em que fragmentos de fórmulas herdadas alternam com tomadas de posição que já não têm nada de pacifistas. Assim, Lévy Mas ataca o "palavreado nacionalista" ao exclamar: "nenhum francês se negará a defender seu território contra uma nova invasão do estrangeiro!” (MARTIN DU GARD, 1964, p. 156). O discurso 
Linha D'Água (Online), São Paulo, v. 29, n. 2, p. 5-41, dez. 2016

dominante dos socialistas do tempo da guerra já está preparado e triunfará em breve. $\mathrm{O}$ que pode fazer um homem solitário, fiel aos princípios do movimento e de um partido, quando os membros deste dão as costas a suas antigas posições? $\mathrm{O}$ triunfo do orador do qual goza Jacques Thibault não é mais que uma vitória efêmera. O final do episódio destaca isso claramente. A multidão, até esse momento, entusiasmada, volta à desordem anárquica da qual o discurso de Jacques só the tirou um momento: "se precipitaram atropeladamente em direção às saídas". Mais do que isso, quando os militantes chamam o orador a gritos, este já não aparece. Sem forças, afunda em um "naufrágio" que não é apenas do esgotamento individual. "O orador havia perdido sua importância em meio à fumaça dos bastidores. Sentado em uma caixa atrás de um monte de decorações antigas, encharcado de suor, febril e abatido, permanecia aqui com os cabelos desordenados, os cotovelos sobre os joelhos e os punhos nos olhos, sem outro desejo, neste naufrágio, que permanecer a maior parte do tempo só, perdido e escondido de todos" (MARTIN DU GARD, 1964, p. 162). O esforço supremo de Jacques é uma tentativa insignificante ou, pelo contrário, o comportamento heroico de um pacifista que luta até o fim, contra todos, pelas convicções que os outros estão dispostos a abandonar?

O narratário, o leitor inscrito no texto a que se propõe esta questão, difere em todos os aspectos do auditório de Jacques. Primeiramente, não constitui um bloco unificado por um pertencimento ideológico comum: o público procurado pelo narrador anônimo é indiferenciado. Entretanto, comporta certas características comuns. Para começar, com relação ao discurso de Jacques, há uma distância temporal que lhe permite lê-lo sabendo de antemão que nenhuma tentativa pacifista poderá impedir a guerra. Sabe-se que os esforços desesperados do protagonista são em vão, enquanto que este ainda tem esperança. Além disso, conhece o discurso socialista e o essencial de sua argumentação pacifista, ainda que pessoalmente não se adira ao mesmo. A este saber enciclopédico básico acrescentam-se certos valores inscritos indiretamente no texto, que pressupõem um acordo prévio do auditório heterogêneo. Com efeito, só a ativação destes valores implícitos permite captar e participar do problema suscitado pelo narrador. A embriaguez do poder que prevalece sobre o sentido da responsabilidade e o prazer narcisista de refletir-se na imagem que lhe transmite a multidão são percebidos como atitudes reprováveis 
Linha D'Água (Online), São Paulo, v. 29, n. 2, p. 5-41, dez. 2016

em função de uma moral que condena a vaidade e os desejos da onipotência do eu. No plano da ética política (e não apenas da moral individual), o narratário que se inscreve no texto é um cidadão que condena as manipulações demagógicas. A ambivalência do protagonista e o problema que provoca o texto respondem a isso.

Em sua função de dramaturgo que recusa um juízo de valor, o narrador de Os Thibault permite um modo de intervenção particular que substitui a afirmação contundente de uma tese por um problema. Ali onde o personagem desenvolve um discurso que busca alcançar a adesão e suscitar uma ação imediata por parte de seu auditório, o narrador propõe ao leitor um texto que revela uma problemática e que o convida a refletir. Jacques quer dar respostas; o narrador invisível do romance convida para a reflexão e para a meditação. Além disso, os temas que ele submete à meditação do leitor se separam dos que o herói desenvolve diante de seu auditório. Um fala dos meios para impedir a guerra, custe o que custar; o outro explora as possibilidades do indivíduo e os limites éticos do discurso público nos tempos de crise. Um quer convencer sobre as teses do pacifismo integral, o outro suscita um problema em torno da validade e da qualidade de sua ação. Nesse sentido, não se pode dar o mesmo sentido à argumentação do personagem e à do narrador anônimo: a primeira busca dar respostas que permitam a intervenção no real; a segunda abre um debate que contempla os elementos, mas não dá uma resposta definitiva.

Compreende-se, pois, a distância que separa o dispositivo enunciativo do artigo de Romain Rolland e o do fragmento relacionado de Os Thibault. Em ambos os casos, impõe-se um modelo interacional no qual o locutor (o orador) se dirige a um destinatário (o auditório) em função da imagem que se faz dele e das crenças que lhe são supostas. No entanto, a interação do relato, contrariamente à que se realiza no jornal de Genève, é dupla, pois a relação do orador de ficção e de seu público é substituída pela do narrador e de seu narratário. Esses planos diferentes se desenvolvem em momentos temporais distintos e se inscrevem em âmbitos institucionais diferenciados. A arenga do protagonista realiza-se em 30 de julho de 1914 e é pronunciada em um comício socialista no qual Jacques, revestido tão somente da autoridade que lhe outorga sua condição de militante, deve criar uma credibilidade jogando com as regras bem determinadas do discurso pacifista. Respeita o enquadre do discurso no comício e tira partido das reações que prevê. A 
Linha D'Água (Online), São Paulo, v. 29, n. 2, p. 5-41, dez. 2016

palavra do narrador não tem data, mas é posterior a esse acontecimento, sem lugar a dúvidas. Respeita a perspectiva do romance realista, no qual o narrador em terceira pessoa, investido de um saber prévio e digno de confiança, "representa" uma cena vivida e mostra sua cara oculta ao leitor.

Além disso, esse narrador anônimo remete à imagem do autor que figura na capa do livro. Quando publica O verão de 1914, o autor de Os Thibault já é conhecido e sua autoridade como escritor desejoso de felicidade histórica e de verdade está consagrada. Uma terceira perspectiva institucional se configura assim, perspectiva que une o autor e seu suposto leitor em 1936, isto é, em uma época em que a ameaça de uma conflagração aflige as mentes e na qual as perguntas angustiadas do romancista sobre a guerra encontram eco de forma inevitável na atualidade.

A questão suscitada pelas palavras e pelo comportamento de Jacques remete, de forma implícita, ao tema da atitude que deve ser adotada nos anos 30 diante da eventualidade de uma nova guerra mundial. Além disso, questiona as vias públicas e os limites éticos de sua eloquência não a partir do exemplo claro (e expressamente condenado por Roger Martin du Gard) da demagogia fascista, mas a partir do problema da eficácia suscitada por uma posição de esquerda em plena Frente Popular. Vê-se como a imbricação de três planos argumentativos no texto romanesco provoca uma complexidade à qual não aspira ao discurso pacifista de Romain Rolland, no qual um escritor reconhecido usa sua autoridade como intelectual para tentar alterar o rumo da opinião no sentido contrário ao do consenso.

\section{Conclusão}

Esta análise sucinta, apresentada como ilustração, apresenta um caso particular que não deve ser generalizado. De fato, a dimensão argumentativa do relato de ficção depende de um dispositivo enunciativo que pode apresentar variações consideráveis. As possibilidades narrativas permitem configurações mais ou menos complexas que possuem um funcionamento argumentativo e um potencial persuasivo diferente.

Como não podemos continuar aprofundando, nos contentamos em destacar alguns pontos. Primeiro, o estudo do discurso argumentativo, ou da dimensão argumentativa do texto literário, passa pela análise de seu dispositivo enunciativo. A 
Linha D'Água (Online), São Paulo, v. 29, n. 2, p. 5-41, dez. 2016

partir desse ponto de vista, a literatura de ideias não se diferencia do relato de ficção. A inter-relação do locutor e do destinatário, tal como se desenvolve no discurso, revela-se determinante. Desse modo, pode-se esboçar um modelo de base com o auxílio dos instrumentos da retórica e da pragmática, modelo que deve se adaptar às necessidades específicas do relato com o apoio das noções elaboradas pela narratologia. Portanto, não há uma ruptura entre discurso político, literatura de ideias, relato de ficção, mas, pelo contrário, há modulação, transformação e maior complexidade. $\mathrm{O}$ discurso argumentativo, seja ele qualificado ou não como literário, deve ser estudado pela sua intenção principal que é influir sobre o destinatário, seja para que este adira a uma tese, seja para lhe orientar em sua visão sobre as coisas, ou para suscitar uma problemática. Ele deve ser estudado não só em termos das estratégias discursivas que se inscrevem na materialidade da linguagem, mas também em sua forma de lidar com o implícito e o estereotipado e na forma de ajustar-se a um imaginário social. Deve também demarcar-se em um contexto institucional no seio do qual se efetua, a priori, uma distribuição de papéis e um reconhecimento do status e das posições que são de importância capital na força do argumento.

\section{Referências}

ADAM, Jean-Michel. Les textes: Types et prototypes. Récit, description, argumentation, explication es dialogue. Paris: Nathan, Fac. Linguistique, 1993.

ADAM, Jean-Michel. Le texte narratif. Paris: Nathan, Fac. Linguistique, 1994.

AMOSSY, Ruth. La confession de Raphaël: contradictioris et interferences. In: Balzac et La Peau de Chagrin, études réunies par Claude Duchet. Paris: CDU-SEDES, 1979. p. 43-59.

AMOSSY, Ruth. Stéréotypie et argumentation. In: GOULET, Alain (ed.). Le Stéréotype. Caen: Presses Universitaires de Caen, 1995.

AMOSSY, Ruth. Cliché et Pathos: l'instigation à la violence. In: RAYNAUD, Claudine; VERNON, Peter (eds.). Graat, numéro special "Fontions du Cliché. Du banal à la violence". 1997. p. $15-28$. 
Linha D'Água (Online), São Paulo, v. 29, n. 2, p. 5-41, dez. 2016

AMOSSY, Ruth; HERSCHBERG-PIERROT, Anne. Stéréotypes et clichés. Paris: Nathan, 1997.

AMOSSY, Ruth; HERSCHBERG-PIERROT, Anne. La France contre Rornain Rolland. Des usages de l'argument ad hominem. In: DUMASY, Lise (ed.). Pamphlets, Manifestes, Utopie. Paris: L'Harmattan, 1998.

ANSCOMBRE, Jean-Claude; DUCROT, Oswald. L'Argumentation dans la langue. Liège: Mardaga, 1988.

ARISTÓTELES. Rhétorique. Introduction de Michel Meyer. Paris: Livre de poche, 1991.

BAKHTINE, Mikhail (VOLOCHINOV, V.N.). Le marxisme et la philosophie du langage. Essai d'application de la méthode sociologique en linguistique. Paris: Minuit, 1977.

BALZAC, Honoré de. Le Colonel Chabert. Paris: Gallimard, Folio classique, 1994.

BENVENISTE, Émile. Problémes de linguistique générale I. Paris: Gallimard, 1966.

BRETON, Philippe. L'Argumentation dans la communication. Paris: La Découverte, coll. Repères, 1996.

DECLERCQ, Gilles. L'art d'argumenter. Structures rhétoriques et littéraires. Paris: Éditions Universitaires, 1992.

DUCROT, Oswald. Dire et ne pas dire. Principes de sémantique linguistique. Paris: Hermann, 1972.

DUCROT, Oswald. Le dire et le dit. Paris: Minuit, 1984.

ECO, Umberto. Lector in Fabula ou les coopérations interprétatives dans les textes natratifs. Paris: Grasset, Biblio Livre de poche, 1985.

FORESTIER, Georges. Introduction à l'analyse des textes classiques. Éléments de rhétorique et de poétique du XVII siècle. Paris: Nathan, 1993.

GARDES-TAMINE, Joëlle. La rhétorique. Paris: Colin, Cursus, 1996.

GENETTE, Gérard. Figures III. Paris: Le Seuil, 1972. 
Linha D'Água (Online), São Paulo, v. 29, n. 2, p. 5-41, dez. 2016

GIONO, Jean. Écrits pacifistes. Paris: Gallimard, Idées, 1978.

HALSALL, Albert W. Victor Hugo ou l'art de convaincre. Le récit hugolien: rhétorique, argumentation, persuasion. Montréal: ed. Balzac, L'Univers des discours, 1995.

ISER, Wolfgang. L'acte de lecture. Théorie de l'ejjét esthétique. Liège: Mardaga, 1985.

JAUS, Hans Robert. Pour une esthétique de la reception. Paris: Gallimard, Tel, 1978.

KERBRAT-ORECCHIONI, Catherine. Les interactions verbales, t. 1. Paris: Colin, 1990.

KIBÉDI-VARGA, Aron. Rhétorique et Littérature. Études de structures classiques. Paris: Didier, 1970.

MCKEON, Zahava Karl. Novels and Arguments. Inventing Rhetorical Criticism. Chicago \& London: The University of Chicago Press, 1982.

MAINGUENEAU, Dominique. Le contexte de l'oeuvre littéraire: Enonciation, écrivain, société, Paris, Dunod, 1993.

MAINGUENEAU, Dominique. L'analyse du discourse en France aujourd'hui. In: Le discours: enjeux et perspectives, Le Français dans le monde, juillet, 1996a. p. 8-14.

MAINGUENEAU, Dominique. Les termes clés de l'analyse de discours. Paris: Le Seuil, Mémo, 1996b.

MARTIN DU GARD, Roger. L'Été 1914. Paris: Gallimard, La Pléiade, 1964.

PERELMAN, Chaïm; OLBRECHTS-TYTECA, Lucie. Traité de l'argumentation. La nouvelle rhétorique. Bruxelles: Presses de l'Université Libre de Bruxelles, 1970.

PERELMAN, Chaïm. L'empire rhétorique. Paris: Vrin, 1988.

PLANTIN, Christian. L'argumentation. Paris: Le Seuil, Mémo, 1996.

PLANTIN, Christian. L'interaction argumentative. In: Dialogue in the Heart of Europe. Congrés de l'IADA, Prague, 1996b. 
Linha D'Água (Online), São Paulo, v. 29, n. 2, p. 5-41, dez. 2016

PRINCE, Gerald. Introduction á l'étude du narrataire. In: QUÉFFELEC-DUMASY, Lise; LOUETTE, Jean-Frangois (eds.) Que prouve la littérature? Fiction et Argumentation. Dix-Neuf/ Vingt 3, mars, 1973.

ROBRIEUX, Jean-Jaques. Éléments de Rhétorique et d'Argumentation. Paris: Dunod, 1993.

REBOUL, Anne. Rhétorique et stylistique de la fiction. Nancy, 1992.

REBOUL, Olivier. Introduction à la rhétorique. Paris: PUF, 1991.

ROLLAND, Romain. Au-dessus de la mêlée. Paris: Ollendorf, 1916.

SULEIMAN, Susan. Le roman à these ou l'autorité fictive. Paris: PUF, Écriture, 1983.

VAN EEMEREN, Frans H.; GROOTENDORST, Rob.; SNOEK HENKEMANS, Francisca. Fundamentals of Argumentation Theory. NJ: Lawrence Erlbaum, 1996.

VIALA, Alain. Sociopoétique. In: MOLINIÉ, Georges; VIALA, Alain. Approches de la réception. Sémiostylistique et sociopoétique de Le Clézio. Paris: PUF, Perspectives littéraires, 1993.

Recebido em 07/08/2016.

Aprovado em 13/09/2016. 